\title{
How the Local People Face the Rapid Change of the Tropical Freshwater Wetland Environment
}

\author{
Krisdianto $^{1}{ }^{*}$, Slamat $^{2}$, Pahmi Anshary ${ }^{2}$, Anang Kadarsyah ${ }^{1}$, Ika Oksi Susilawati ${ }^{1}$ \\ 1) Lambung Mangkurat University, The Faculty of Mathematics and Natural Science. \\ 2) Lambung Mangkurat University, The Faculty of Fisheries and Marine Science.
}

\begin{abstract}
Barito River crosses from the northeast of Central Kalimantan province, but almost two-third of $1000 \mathrm{~km}$ length lies in South Kalimantan. While water comes from Schwaner Mountain in the upper, this river receives water from Meratus pass through five big rivers, such as Tabalong, Batang Alai, Pagat, Amandit, and Riam Kiwa. Before the water flowed into Barito River, it retains for sometimes in the low land swampy area, forming huge lowland muddy into shallow lakes, simply named wetlands. How do people commit to sustainability living in extreme tropical wetlands for generations? The ecological investigation was conducted for 2016 - 2019, in-situ observation on the daily life-behavior of local people of 200 local people living Barito Kuala, Tapin, Hulu Sungai Selatan, Hulu Sungai Tengah, Hulu Sungai Utara residences, their technologies, their progress in sustainability development. Data was collected by interviewing directly to the local, face to face, meeting with family, observing and confirming nature with them, as well as studying scientific articles and grey literature from official reports. Statistical calculation helps to compare several data sets, as well as serial of photographs, which documented to support the evidence visually. In conclusion, the locals face the rapid change environments which influence their life, income, health, and their properties and prosperity. Mostly, they complain that life is much more difficult now than several decades ago.
\end{abstract}

\section{Introduction}

Environmental degradation in Kalimantan has been started in the logging era about five decades when Indonesia needed high fund to support their physical development. Forest exploitation became a formal income in New Order (ORBA) era. The effect is not just reducing water quality or land clearing, but also stimulating forest fire in the dry season. About thousand ha forest was burnt down in the dry season of 1998. In New Order, after 1998, new government start extraction coal, using open-pit methods. The rest untreated water flows into the rivers and results in high turbidity in river water, especially in monsoon. When the world price of coal decreases, the government lets corporations for planting oil palm di ex-mining area [1].

Oil palm occupied extensively land, a massive change on forest cover into oil palm. Rainwater directly removes from plantation to the lower place, because of lower absorption by oil palm forest floor, run-off water rapidly falls into the rivers. Water pollution increases in the rain season and decrease in summer. Oil palm plantation is a more homogenous cover and reduces biodiversity, habitat, especially plants. Extensive dystrophic lakes in the water body occur due to humic substances and organic acid removing by runoff water and created a new shallow-water zone in some places. All of the disturbance can reduce water quality with $\mathrm{pH}$ $4.0-6.0$ and brown color, which affects vegetation and succession in rivers or lakes [2].

During summer, weather in the highland area becomes faster and dryer, rainwater displacement very fast, falls into the river to settle in lowland swampy, Barito River basin. Water will remain here for some time, depended on the Barito river surface, in some places retained just about three, six, or even nine months. However in the long dry season, the retaining water just in a shorter time. Local people become fishermen in the rainy, farmers in the dry season. People who are ready in skill and knowledge both in dry and rainy seasons will have benefit, but some of them are just a fisherman or farmer will reduce their income in certain seasons. Wiegleb et.al. reviewed the benefit of wetlands and at the same time [3], Samdeliri and Shahbazi were valuation wetlands for recreation in ShirinSou wetland, as a comparable effort to describe locals involvement in wetland management [4].

Local people become fishermen in the rainy, farmers in the dry season. People who are ready in skill and knowledge both in dry and rainy seasons will have benefit, but some of them are just a fisherman or farmer will reduce their income in certain seasons. This research discovers what people are both as farmer and fisherman to adapt, and the local change activities for financing their life.

\section{Methods}

A survey for selecting research areas was conducted in 2017 around the Barito river and its streams than were interviewing for local people in some villages to record their concern about the change of their environment by using questioner and focus group discussion approach, involving about 300 people from 6 villages, such as Asia Baru, Jaranang, Tampakang, Balarawa, Samhurang. The ecological approach was considered the following methods proposed by Hanson et al. [5]. Personal visiting to where the selected fisherman and farmer for

\footnotetext{
Corresponding author: krisdianto@ulm.ac.id
} 
confirmation interview. Quantitative data were statistically analyzed to support the conclusion.

\section{Results and Discussion}

About $96 \%$ of fishermen (more than 40 years old) said that the environment has changed and more difficult to get yield both from rice fields and rivers (collecting fish). In this case, local people blame electrofishing, causing disappeared of fingerling of any kind of fish. The government has produced regulation that stated electrofishing is illegal and also broke the role of conservation too. However, it is not easy to control a huge wetland area, and the pirates can enter from different areas from both land or rivers. This government needs more facilities and regulations to control this area. Especially when the pirates are using big engine capacity boats and weapons.

All of them blame the oil palm plantation as the cause of reduction or fail of their yield, also limiting area for hunting or producing waste to polluting water in the rainy season. However, all of them agree that the change in harvesting also caused by uncertain season/ climate change. Long dry season can increase the possibility of a forest fire, and long rains season can stimulate local storm. In these cases, local people don't have skills and sufficient equipment to solve the problems.

Almost all of them get difficulties to earn money, loss of jobs, fail in fish, and rice harvest. These shifting stories occur from year to year. The government has expenditure budgets for helping them, but it is not regular expenses. Local people must learn to overcome their problems. Some farmers are not just harvesting rice, they also take advantage of local plants, such as Water Chestnut for creating bags or other ornamental decoration. In this case, locals just need more skills to design their products. Some gathering forums have run regularly to increase their skill, connect to the shop owners, market agents, or attend international events.

They are aware that they have no such skill in modern jobs, lack of formal education. These problems may not a handicap if locals can create a community or corporation which can hire experts on digital marketing. The government has provided guides, or trainers, or supervisors to coach, or train farmers or fishermen, also creates groups or networks of both of them. Banks, cooperation boards, and the government itself have provided loans or grants to finance local activities. However, some local people have low work performance, so most of them lose the opportunity to access loans or grants.

Some fishermen have a certain area for aquaculture and conserve the area for fingerling. Some of them have been already learned as a farmer in dry and as a fisherman in rainy seasons. Others developed horticulture, a short period of vegetables, and fruits during the dry season in dry wetland, while in some places land submerged during high flooding. Water soaks the land and brings some natural fertilizer. This cycle brings advantage in the dry season, farmers do not need plenty of fertilizer to get the best harvest.
Some of them invest in the new business as ediblenest swiftlet production, swiftlet saliva is a new business in Barito Basin, Originally, nest-swiftlet is located in the eastern beach of South Kalimantan. However the last two decades those areas were extensively opened for oil palm plantation and some lime mining for cement industries. Then, swiftlet may migrate to the west, Barito Basin where plenty of insects grow in the wetland. Just for the last three years, there are more than a hundred barn swallows were constructed (Figure 1). Locals were involved in cooperation with investors. Compare with other businesses in wetland, edible-nest swiftlet can be projected as a big business in the future.

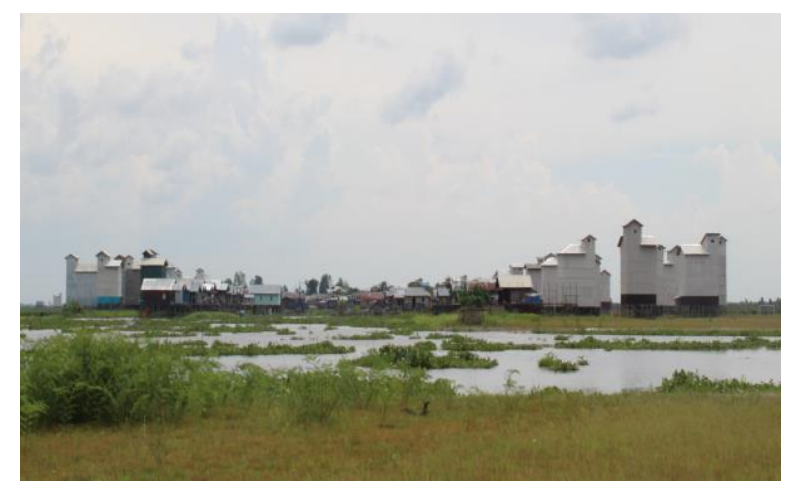

Figure 1. Wooden barn for edible-nest swiftlet.

Ranching buffaloes is a traditional activity in wetland, the owner recruits some workers, as buffaloboy, sailing a wooden canoe for directing buffalo to the grazing areas during the day (Figure 2), and returning to ranch in the late afternoon. There are about five thousand buffaloes distributed on the basin. For locals captivity, buffalo are not just for earning money, but also for saving. They will sell those buffaloes when other people need meat for the traditional ceremony. The average price for 1,5 or 2 years old is about 15 million rupiahs.

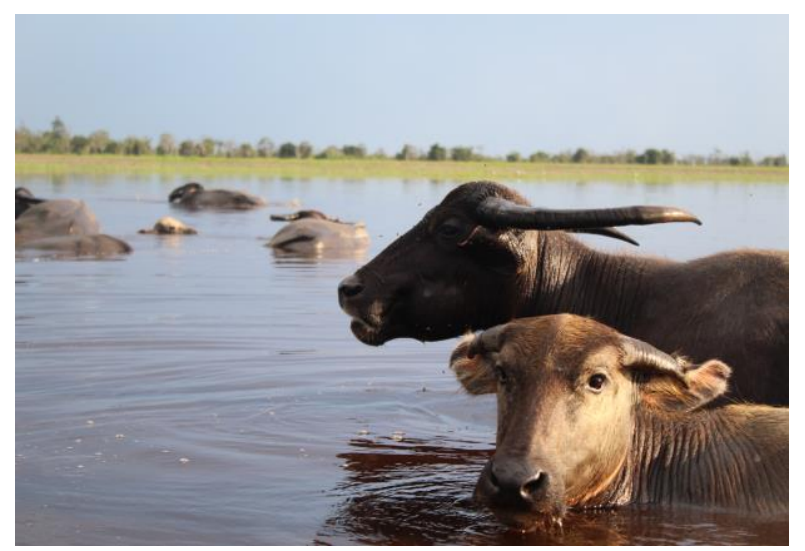

Figure 2. Swimming buffalo in Panggang Lake.

Buffalo ranching in water, they are grazing in the day time and return home in the evening. They have plenty of food in the rain season, in the dry season, some buffalo are dying because of starving.

People continue harvesting water grass as raw materials for home industries. Chinese nutgrass formerly grows freely in adjacent land water (Figure 3). People harvesting the grass and make them for ornamental mats 
and sacks for packaging exported tobacco. Especially, women make and sell it to the collector for exporting to Malaysia. Every three months, they can sell about some containers and get about 1,000,000.000 rupiahs average. This result is comparable to that in Bangladesh [6].

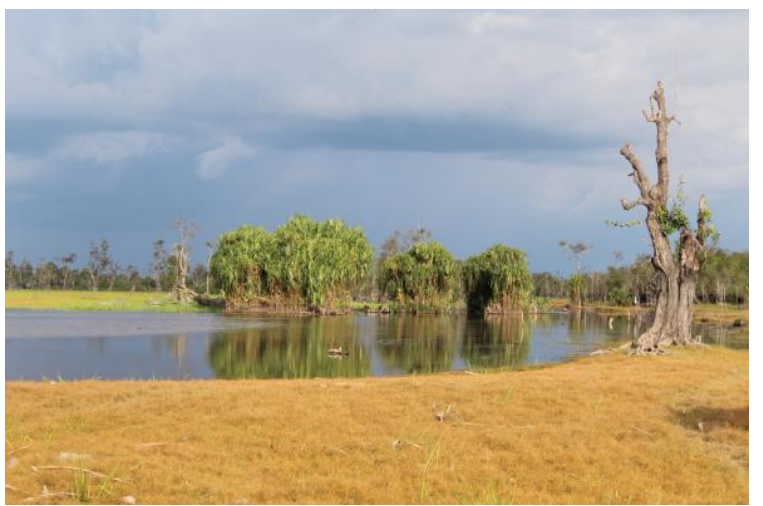

Figure 3. Peat dome in the dry season, a place for harvesting grass

Fishermen develop their skills to respond to the change of environment. For example, they make equipment, a combination of fabricated and natural materials to create a piece of equipment for catching fish (Figure 4).

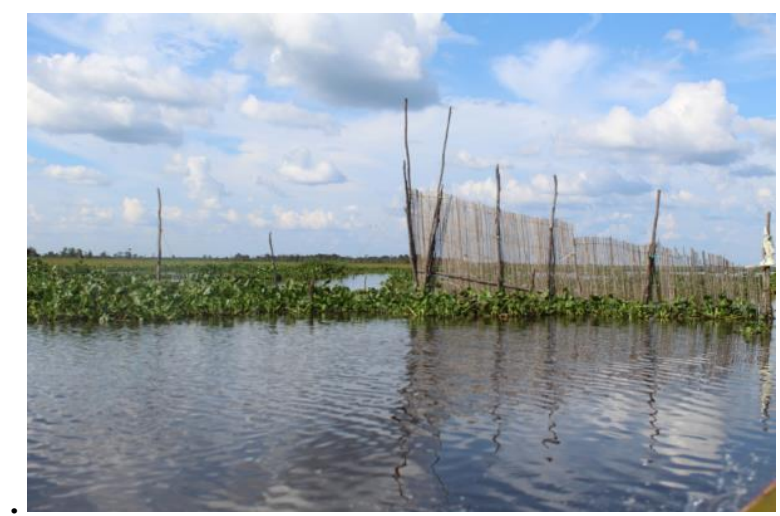

Figure 4. Fish trap, a combination of bamboo and fiber net.

In dry season water level drop, a fisherman can catch the fish by himself, without assistance from others. He circles the net, and step by step set the net to become smaller. Finally, he can catch the fish easily. In the right weather, he can collect 5 to $10 \mathrm{~kg}$ per day. Fisherman also uses trash fish for feeding in culturing or used it as an attractant for bigger fish. Trash fish has collected from the smaller size, has no economic value. This fish actually foods for the biggest fish.

\section{Conclusion}

Historically, Banjarese is one of the stakeholders who directly involve in managing Barito River for centuries and its wetland. Their experience, knowledge, skills from generation to generation is an asset that should not remove from modern wetland management. In the era of uncertainty and environmental degradation, as we are in right now, their experience perhaps still becomes a feasible solution at a certain level for community or society in managing sustainable natural resources. This research concludes that not all wetland areas are necessarily converted into the modern oil-palm plantation in the case of developing a wealth of the local. Local people have a preferable commodity, production, and local wise technology which are culturally decent from their old generation, local wisdom. Their spirit may possible to develop their way of life, which is the meaning of freedom and democracy.

\section{References}

1. Mukhlisi, Reklamasi Lahan Pasca Tambang: Aspek Kebijakan, Konservasi dan Teknologi (BPTKSDA, 2013)

2. H. Yu, W. Qi, C., Liu, L. Yang, L. Lv, T. Wang, , and J. Peng Water 11, 1412 L. Lv, T. (2019)

3. G. Wiegleb, Dahms, H-U., Byeon, W.I., and Choi, G. IJESD, 8,8 (2017)

4. S.A. Samdeliri and Shahbazi, H. 2017. IJAMAD. 7,1 (2017)

5. Hanson, L. Swanson, D. Ewing, G. Grabas, S. Meyer, L. Ross, M. Watmough, and J. Kirkby Wetland ecological functions assessment: An overview of approaches. Technical Report Series. 497. Canadian Wildlife Service Atlantic, (2018)

6. Md. S. Hossain and S. Szabo. Wetland Science. Springer, India, (2017) 